\title{
Laser-Induced Breakdown Spectroscopy and Phytolith Analysis: An Approach to Study the Deposition and Distribution Pattern of Silicon in Different Parts of Wheat (Triticum aestivum L.) Plant
}

\author{
Durgesh Kumar Tripathi • Rohit Kumar • \\ Ashok Kumar Pathak • Devendra Kumar Chauhan • \\ Awadhesh Kumar Rai
}

Received: 8 February 2012/ Accepted: 1 November 2012/Published online: 28 November 2012

(c) NAAS (National Academy of Agricultural Sciences) 2012

\begin{abstract}
The distribution/deposition pattern of silicon and minerals in different parts of wheat (Triticum aestivum) plants was determined using laser-induced breakdown spectroscopy (LIBS) and phytolith analysis. The LIBS spectra of different parts of wheat plants gave spectral signature of $\mathrm{Ca}, \mathrm{Mg}, \mathrm{Si}, \mathrm{Fe}, \mathrm{Na}, \mathrm{K}, \mathrm{C}, \mathrm{H}, \mathrm{O}$ and $\mathrm{N}$. Phytolith analysis showed that the leaves of wheat plants are the highest silicon accumulator followed by the awn, leaf sheath, lemma, rachilla and stem. The results of LIBS analysis and the phytolith analysis were in close agreement. The multivariate statistical analysis, principal component analysis (PCA), was applied to the data set of the LIBS spectra of the different parts of the wheat plants. PCA on LIBS data matrix gives PC1 $(99 \%)$ and PC2 $(1 \%)$ which explains the $100 \%$ variance in the data set. The PCA plots discriminate the vegetative and fertile parts of the wheat plant. Furthermore, the appearance of silicon in each part of the wheat plants also demonstrates its significance in biocement production.
\end{abstract}

Keywords LIBS $\cdot$ Phytolith $\cdot$ Poaceae $\cdot$ Silicon $\cdot$ PCA

\section{Introduction}

Plants absorb silicon in the form of monosilicic acid from the soil through roots and deposit it in the form of opal silica in epidermal, cortical and vascular tissues [24]. The role of silicon is reported to reduce the effects of salt stress, drought stress, metal toxicity, nutrient imbalance and radiation damage $[4,8,9,13,44,49,50]$. Silicon reportedly increases crop quality and yield, protects the plants against fungal infection, insects, pest attack and increases disease resistance $[5,17,26,27,38]$. Silicon can also alleviate imbalance between zinc and phosphorus supply as well as decrease the toxic effect of aluminum in

D. K. Tripathi · D. K. Chauhan

Department of Botany, University of Allahabad, Allahabad, India

e-mail: dktripathiau@gmail.com

R. Kumar · A. K. Pathak · A. K. Rai $(\bowtie)$

Laser Spectroscopy Research Laboratory, Department of

Physics, University of Allahabad, Allahabad, India

e-mail: awadheshkrai@rediffmail.com hydroponic culture in several species $[3,9,44,56]$. Similar applications of silicon have also been found in other cereals and dicotyledonous plants [11, 25, 41, 48, 53]. It is also reported that silicon improves nutrient balance in a wide variety of plant species [14, 28, 30]. Ponzi and Pizzolongo [36] have described the morphology and distribution of epidermal phytoliths in Triticum aestivum. Some other silicon-related aspects in various plants have also been discussed earlier by various active researchers $[15,16,21$, 32, 47].

In plants of the Poaceae family phytolith studies have shown that silica is deposited in all parts of the plants in varying concentrations and forms silica short cells, epidermal long cells, bulliform cells and prickle hairs $[6,7$, 52]. Various techniques have been applied to study silicon deposition in plants; these include high temperature alkaline dissolution, gravimetry, hydrofluoric acid dissolution, microwave assisted nitric acid and sodium hydroxide digestion, autoclave-induced sodium hydroxide digestion and electro thermal vaporization combined with inductively coupled plasma atomic emission spectroscopy (ICP-AES) $[12,20,33,34,39,54,55]$. The other techniques which are 
being utilized for elemental analysis of materials are ion mobility spectrometry (IMS) and graphite furnace atomic absorption spectrometry (GFAAS), but all these techniques are expensive and require lengthy and time consuming sample preparation and are not suitable for in situ and point detection analysis. In order to know the distribution and deposition pattern of silicon and other elements in different parts of plants, an analytical technique which has point detection capability is essential. Recently, laser-induced breakdown spectroscopy (LIBS) has emerged as a promising analytical technique for the analysis of spatially-distributed elements in plants and biomaterials [6, 35].

The laser-induced breakdown spectroscopy technique is based on collection of the emission from ionic, atomic and molecular species in the plasma formed due to high power laser and material interaction. LIBS has several unique features like simultaneous multi-elemental monitoring, capability of real time and in situ analysis of material in any phase, i.e. solid, liquid and gas, and requires minimal sample preparation. In recent years silicon-rich plants have been used for the production of biocement. Hosseini et al. [23] have shown that biocement is a blend of bio-silica which requires less energy intensive clinker and have environmental, economic and technical benefits. It has also been proposed that a survey of the silicon content value of the major crops and native plants species is an important step for biocement production. Therefore, the main objective of our work was to know the distribution and deposition patterns of silicon and mineral elements in various parts of wheat (Triticum aestivum) plants with the help of LIBS and phytolith analysis.

\section{Materials and Methods}

Sample Collection, Preparation and Section Cutting

PBW-343 variety of wheat was grown for the experiment. Soil was placed in plastic pots and set on a greenhouse stand at an average temperature of $23{ }^{\circ} \mathrm{C}$ without extra light. Plants were irrigated two times in a week from the tap water and no fertilizers were used during the experiment. At the mature stage (140 days after sowing) of the wheat (Triticum aestivum L.) plant, leaves, leaf sheaths, stem, awn, lemma and rachilla were collected from the Botany Department, University of Allahabad, Allahabad $\left(24^{\circ} 47^{\prime}\right.$ and $50^{\circ} 47^{\prime} \mathrm{N}$ latitude; $81^{\circ} 91^{\prime}$ and $82^{\circ} 21^{\prime} \mathrm{E}$ longitude), Uttar Pradesh, India. Small pieces of leaves were washed in distilled water and made transparent using the technique of Stebbins [45] to see the deposition of silica in different cells at different portions (margins and midrib) of the leaves. Transverse sections of leaves, leaf sheath, stem, awn, lemma, and rachilla were prepared and stained in methyl red [10] to see the deposition of silica in different parts of plant cells.

\section{Biogenic Silica Extraction}

Silica (phytolith) from different parts of wheat was extracted using the dry ash technique [51]. To remove mineral particles from the surface and to soften the mineralized tissue, small pieces of leaves, leaf sheath, stem, awn, lemma and rachilla originating from mature plants were washed thoroughly three times in a mixture of $10 \%$ $\mathrm{HCl}$ and distilled water. Each part of the wheat plant was then dried at room temperature and $1 \mathrm{~g}$ of each sample was placed in a ceramic crucible and washed for at least $6 \mathrm{~h}$ at $600{ }^{\circ} \mathrm{C}$ in the muffle furnace. Ash was treated with $100 \mathrm{ml}$ of $5 \mathrm{~N} \mathrm{HNO}_{3}$ and $\mathrm{KClO}_{3}(1 \%)$ to remove organic material. Residues were washed with distilled water and centrifuged. The remaining biogenic silica residue was dried at $40{ }^{\circ} \mathrm{C}$ and mounted in Canada balsam onto microscopic slides. For each sample (leaf blade, leaf sheaths, stem, awn, lemma and rachilla) five slides were prepared in Canada balsam by taking $0.001 \mathrm{~g}$ ash/slide. The shape, size and frequency of each phytoliths present in each sample were observed in $1.24 \mathrm{~mm}^{2}$ area/slide using a Leica DM 2500 microscope fitted with a digital camera.

\section{Data Analysis}

Statistical analysis of the data was performed using Origin 8.1 software. The mean and standard deviation (SD) were calculated for the analysis of frequencies of phytoliths in different parts of the wheat plant. PCA was applied with the help of Unscrambler $\mathrm{X}$ for the discrimination of data.

\section{LIBS Experiment}

The LIBS experimental set-up (Fig. 1) consists of a broad band spectrometer (Ocean Optics, LIBS 2000+) equipped with charge coupled devices (CCD), a translational stage for holding the target sample (leaf, leaf sheath, stem, awn, lemma, rachilla) and a Nd:YAG laser (Continuum, Surelite III-10). The maximum deliverable pulse energy of the laser at $532 \mathrm{~nm}$ is $425 \mathrm{~mJ}$ with a pulse width of $4 \mathrm{~ns}$ and repetition rate of $10 \mathrm{~Hz}$. The laser energy was measured with a calibrated energy meter (Genetec Model SOLO PE model UP19 K 30H VMDO). The convex lens (focal length $15 \mathrm{~cm}$ ) was used to focus the laser beam onto the target surface to generate the laser-induced plasma. The light emitted from the plasma was first collected with a collecting lens (lens diameter $5 \mathrm{~mm}$, f-number is $\mathrm{f} / 2$ ) fixed at the tip of the fiber bundle and then brought to the entrance slit of the LIBS $2000+$ spectrometer. The spectrometer has three modules to provide high resolution (FWHM $0.1 \mathrm{~nm}$ ) in the $200-500 \mathrm{~nm}$ 
Fig. 1 Laser-induced breakdown spectroscopy (LIBS) setup for recording the LIBS spectra of a plant sample

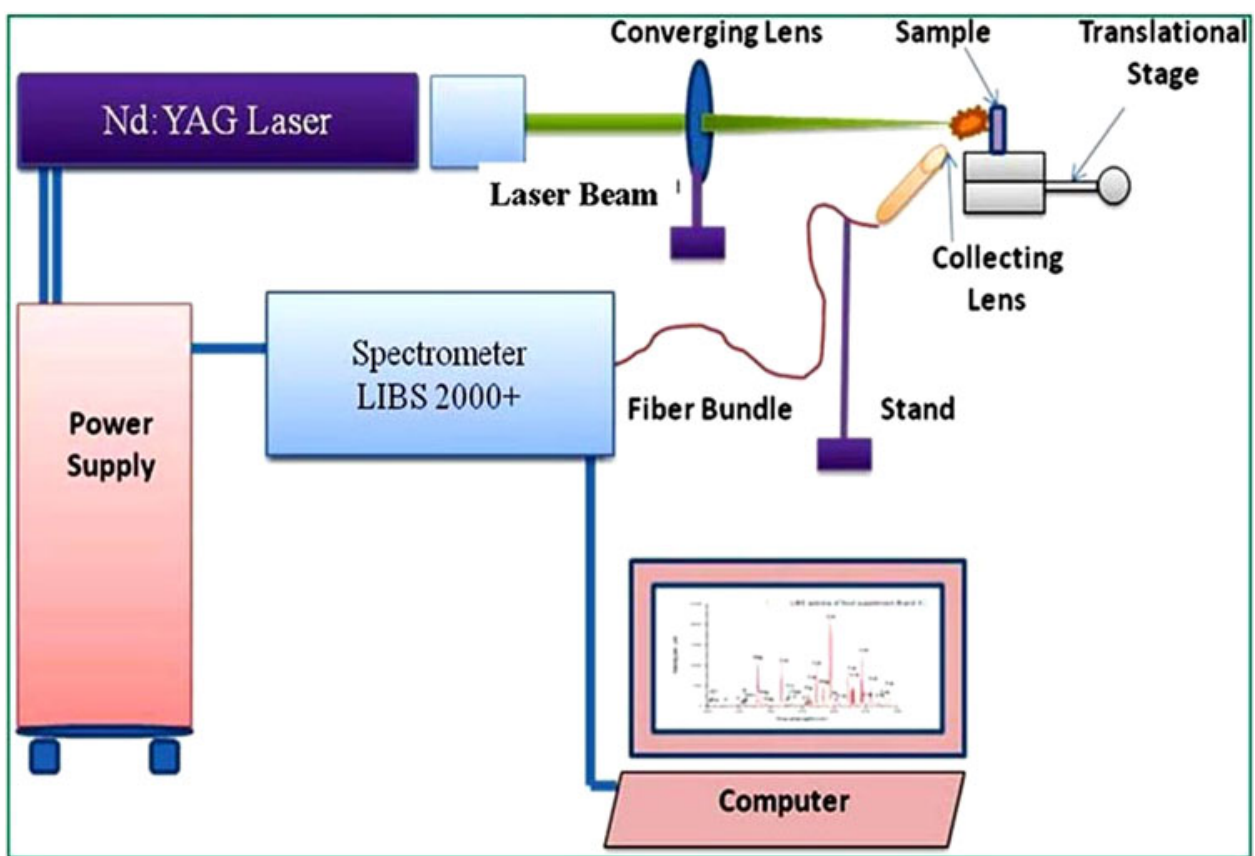

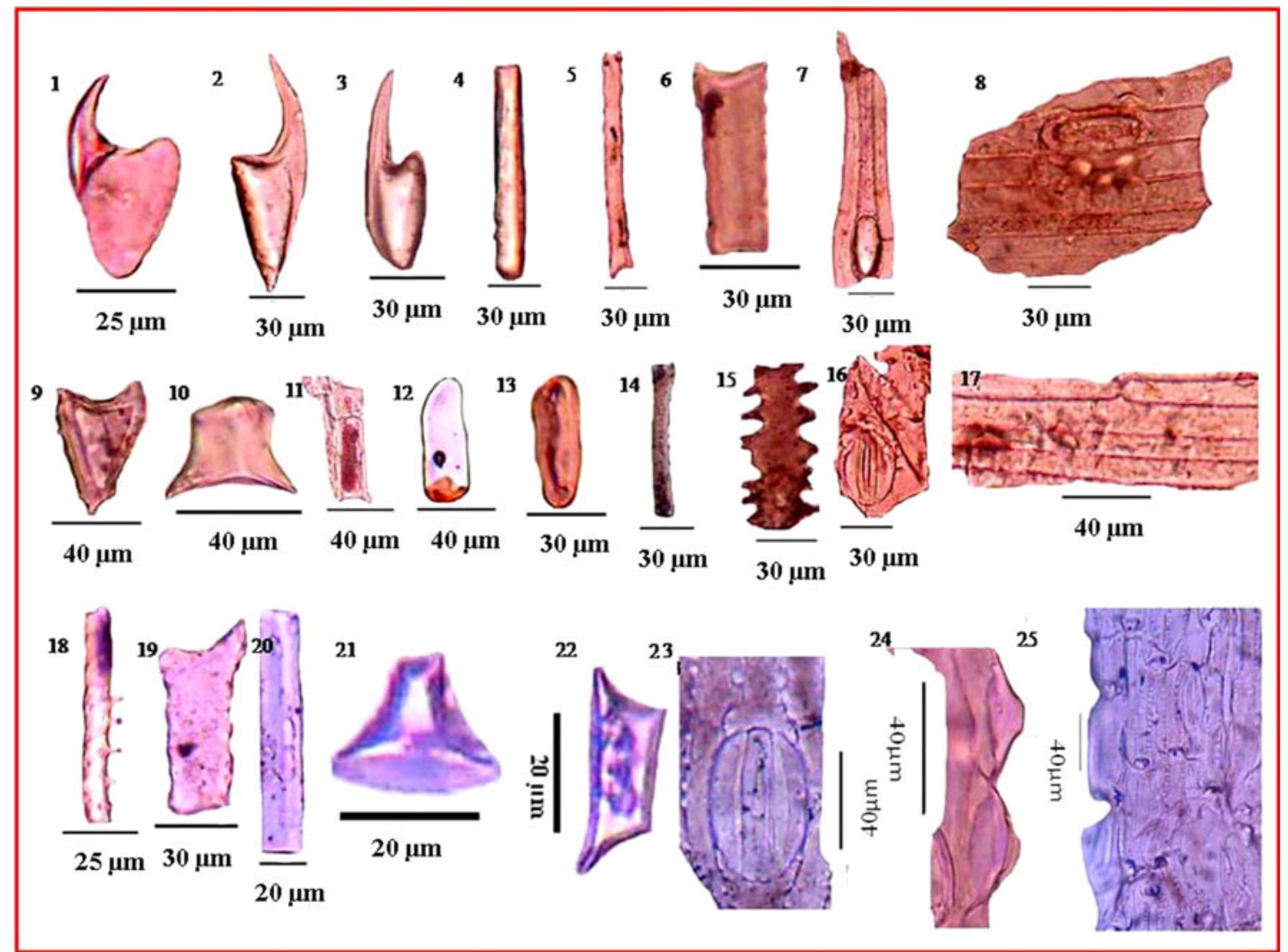

Fig. 2 Presence of silicified cells of Triticum aestivum leaf blade [prickle hair cell (1-3), rod shaped (4), dendriform $(5,6)$, sheet epidermal long cells (7), epidermal cells with stomata (8) and short cells phytoliths], leaf sheaths [prickle hairs (9), trapezoid (10), costal rod shaped $(12,13)$, sinuous rod shaped $(14,15)$, stomata (16) and epidermal cell (17)] and stem of wheat [elongate sinuous phytolith $(18,19)$, rod shaped $(20)$, trapezoid $(21,22)$, stomata $(23)$, papillae (24), epidermal cell (25)] 
wavelength region and a fourth module that has low resolution (FWHM $0.75 \mathrm{~nm}$ ) in the $200-900 \mathrm{~nm}$ wavelength region. To record the LIBS spectra we first dried the wheat plants and converted them to powder, and then one gram of powder from each part was used to prepare the pellets. Pellets were prepared using a pressure of 10 tons with a hydraulic press machine in a $\mathrm{KBr}$ die. LIBS spectra of the pellets of different parts of wheat plants (leaf, leaf sheath, stem, awn, lemma, and rachilla) were recorded by focusing the laser beam onto the surface of each pellet respectively. Each spectrum was based on an average of ten laser shots under optimized experimental conditions.

\section{Results and Discussion}

Phytolith Analysis

\section{Transparency and Dry Ash Technique of Phytolith Extraction}

The phytoliths, obtained by the dry ash method from different parts of wheat plants, were viewed and analyzed using optical microscopy. The phytoliths were found to have a variety of shapes and sizes (Figs. 2, 3). Silicon was deposited in inter- and intra-cellular spaces of different parts of wheat plants. The phytoliths take a very distinctive shape in various parts of the wheat plant, depending on the shape of cells silicified. In the leaf blade, prickle hair cell, rod shaped, dendriform, sheet epidermal long cells, epidermal cells with stomata and short cells phytoliths were present (Table 1). In the leaf sheaths prickle hairs, trapezoid, costal rod shaped, sinuous rod shaped, stomata and epidermal cells were present (Table 1). Stem of wheat produced elongated sinuous phytolith, rod shaped, trapezoid, stomata, papillae and epidermal cells (Table 1; Fig. 2); while deposition of silicon in the fertile parts of wheat plant such as in awn, lemma and rachilla also produced various types of phytoliths, for example, awn of the wheat produced long hair cells, prickle hairs, hair bases, sub epidermal rod shaped and epidermal cells. Lemma produced dendriform phytoliths, rod shaped phytolith, hairs and epidermal cells (Table 1). Rachilla of the wheat plant also produced prickle hairs, fiber cell, dendriform phytoliths and epidermal cells (Table 1). In the last few decades the procedure of phytolith counts showed a great relevance

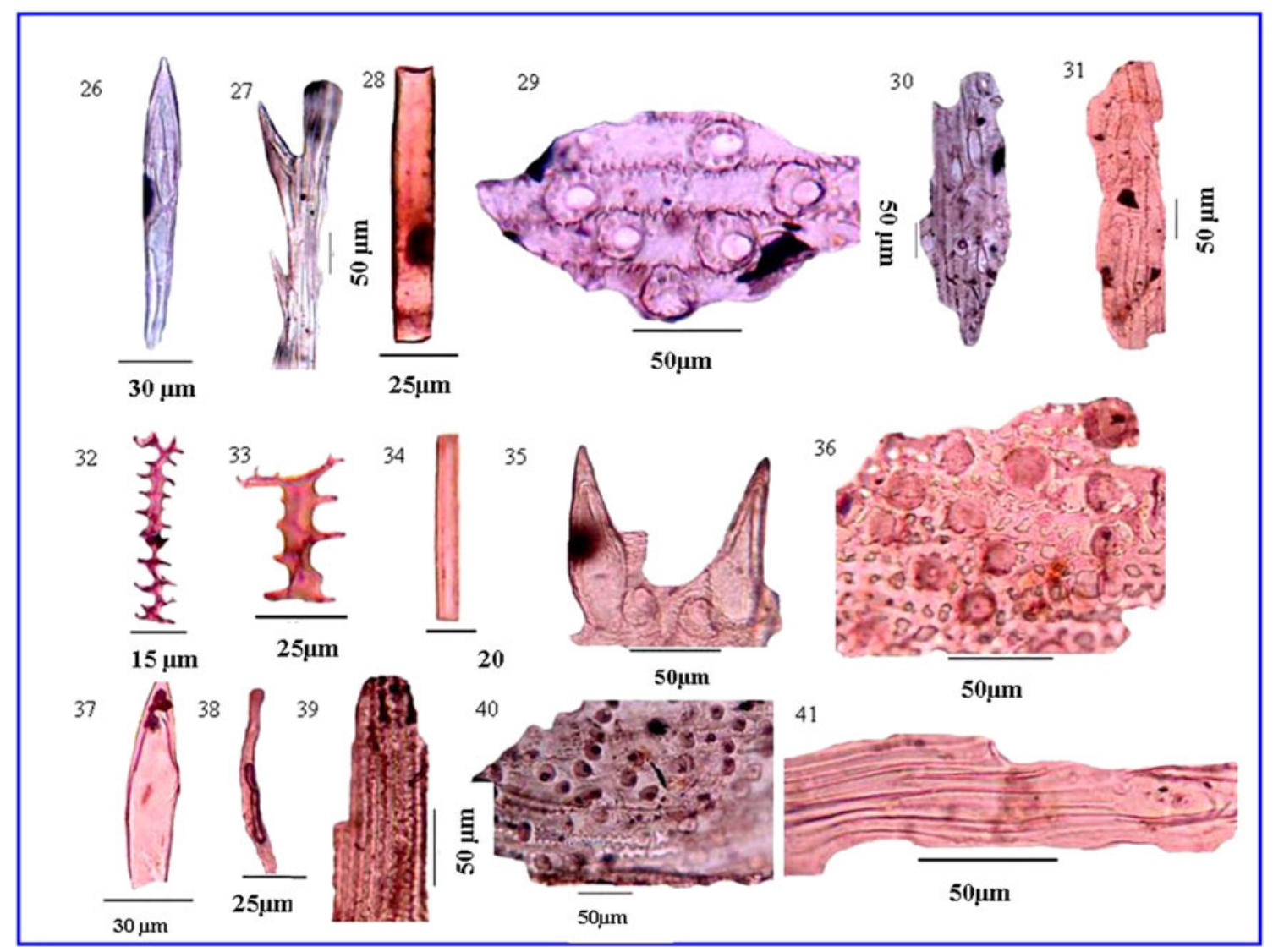

Fig. 3 Presence of different types of silicified cells in Triticum aestivum awn [long hair cell (26), prickle hairs (27), hair bases (29), sub epidermal rod shaped (28), epidermal cell $(30,31)$, lemma [dendriform phytoliths $(32,33)$, rod shaped phytolith 3 (34), hairs (35), epidermal cell (36)] and rachilla prickle hairs (37) fiber cell (38), dendriform phytoliths (39) and epidermal cells $(40,41)$ 
Table 1 Silicified cells present in different parts of wheat samples

\begin{tabular}{|c|c|c|c|c|c|c|}
\hline \multirow[t]{2}{*}{ Type of phytoliths } & \multicolumn{6}{|c|}{ Parts of plants } \\
\hline & Leaf & Leaf sheath & Stem & Lemma & Rachilla & Awn \\
\hline Prickle hair cell & Fig. $2(1-3)$ & Fig. 2 (9) & & & Fig. 3 (37) & Fig. 3 (27) \\
\hline Rod shaped & Fig. 2 (4) & - & Fig. 2 (20) & Fig. 3 (34) & - & - \\
\hline Dendriform & Fig. $2(5,6)$ & - & - & Fig. $3(32,33)$ & - & - \\
\hline Sheet epidermal long cells & Fig. 2 (7) & - & - & - & - & - \\
\hline Epidermal cells with stomata & Fig. $2(8)$ & - & - & - & - & - \\
\hline Trapezoid & - & Fig. 2 (10) & Fig. $2(21,22)$ & - & - & - \\
\hline Costal rod shaped & - & Fig. $2(12,13)$ & - & - & - & - \\
\hline Sinuous rod shaped & - & Fig. $2(14,15)$ & - & - & - & - \\
\hline Stomata & - & Fig. 2 (16) & Fig. 2 (23) & - & - & - \\
\hline Epidermal cell & - & Fig. 2 (17) & Fig. 2 (25) & Fig. 3 (36) & Fig. $3(40,41)$ & Fig. $3(30,31)$ \\
\hline Papillae & - & - & Fig. 2 (24) & - & - & - \\
\hline Hair bases & - & - & - & - & - & Fig. 3 (29) \\
\hline Sub epidermal rod shaped & - & - & - & - & - & Fig. 3 (28) \\
\hline Dendriform & - & - & - & - & Fig. 3 (39) & - \\
\hline Hairs & - & - & - & Fig. 3 (35) & - & - \\
\hline Fiber cell & - & - & - & - & Fig. $3(38)$ & - \\
\hline Elongate sinuous phytolith & - & Fig. $2(18,19)$ & - & - & - & - \\
\hline Long hair cell & - & - & - & - & - & Fig. 3 (26) \\
\hline
\end{tabular}

Numbers in parentheses represent part numbers in the referred figure

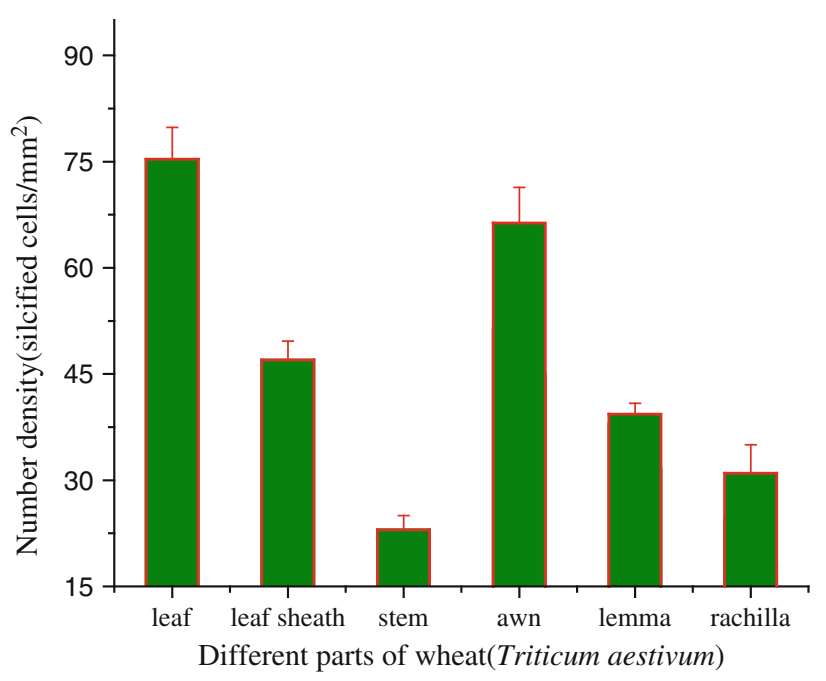

Fig. 4 Distribution of silicified cells in different part of the plant using phytolith analysis

in phytolith studies and has been used by many phytolith researchers $[1,46]$. We have also used this procedure in a fixed observed area of the slides and after counting we observed that the highest silicified cells were present in leaf blade followed by the awn, leaf sheath, lemma, rachilla and stem (Fig. 4). It has been previously reported that the highest silicon percentage was present in major transpiration parts of the plants followed by the other parts of the plants [37]; thus leaf blade contains the highest silicon. In this study the terminology of phytoliths is used according to the International Code of Phytolith Nomenclature 1.0 [31].

\section{LIBS Analysis}

LIBS spectrum of different parts of wheat was recorded in the spectral range of $200-900 \mathrm{~nm}$ to acquire the information of all the minerals/elements present in various parts of the wheat plant. A typical LIBS spectrum of the wheat leaves recorded in different spectral regions (200-900 nm) are shown in Figs. 5 and 6. The characteristic spectral lines of silicon (288.1, 221.1, $252.8 \mathrm{~nm}$ ) along with the spectral lines of other essential elements such as magnesium (279.5, and $285.2 \mathrm{~nm}$ ), calcium $(315.8,317.9,393.3,396.8$ and $422.6 \mathrm{~nm}$ ) aluminum (308.2 and $309.2 \mathrm{~nm}$ ), iron (238.2, $239.5 \mathrm{~nm}$ ), sodium $(589.6,819.4 \mathrm{~nm})$ and potassium (766.4, $769.8 \mathrm{~nm}$ ), etc. were observed in LIBS spectra of the plant samples. In addition to this, the spectral lines of lighter elements like carbon $(247.8 \mathrm{~nm})$, hydrogen $(656.2 \mathrm{~nm})$, nitrogen $(744.2$ and $746.8 \mathrm{~nm})$ and oxygen $(777.2 \mathrm{~nm}$ ) have also been detected in the LIBS spectra of plant samples. The identification of elements [40] is based on the presence of the persistent lines of the elements present in the LIBS spectra of target samples. The variation in intensities of spectral lines (intensity proportional to the concentration) of $\mathrm{Si}(288.1 \mathrm{~nm})$ in the LIBS spectra of different parts of the wheat plant is shown in Fig. 7, which 


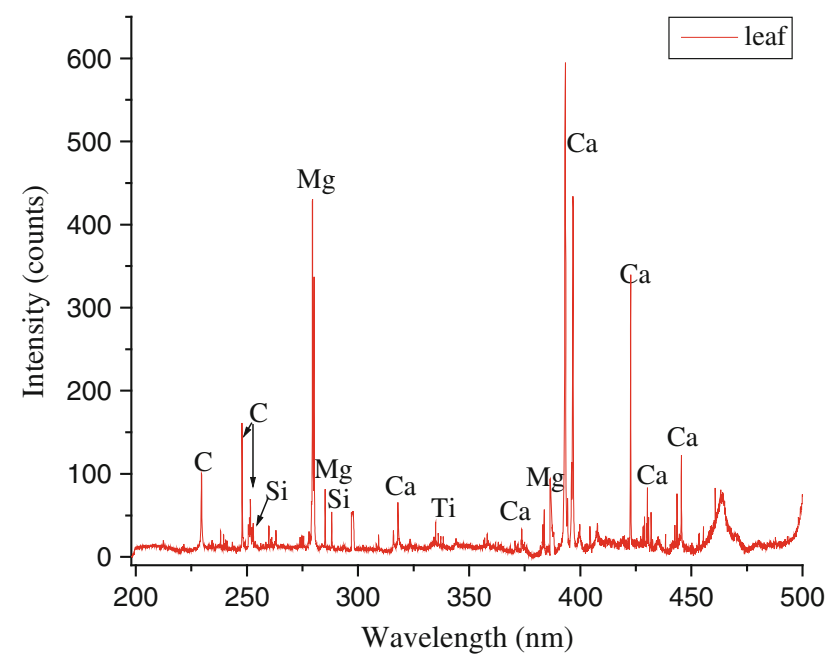

Fig. 5 Laser-induced breakdown spectroscopy (LIBS) spectra from $200-500 \mathrm{~nm}$ of a leaf of wheat plant

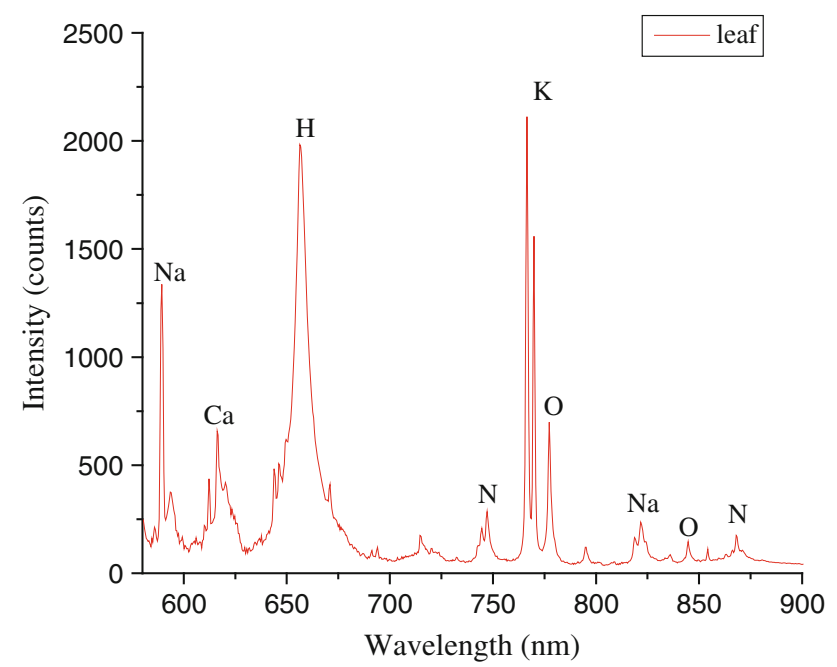

Fig. 6 Laser-induced breakdown spectroscopy (LIBS) spectra from $500-900 \mathrm{~nm}$ of a leaf of wheat plant

clearly reveals that the concentrations of silicon follow the trend: leaf $>$ awn $>$ leaf sheath $>$ lemma $>$ rachilla $>$ stem. Before using the data (intensity) of the spectral lines present in the LIBS spectra of the target sample one has to verify the certain assumption like stoichiometric ablation, optically thin plasma and existence of LTE.

In the present experiment, laser irradiance is $10^{12}$ $\mathrm{W} \mathrm{cm}{ }^{-2}$ which is sufficient for the stoichiometric ablation [43]. In order to verify the optically thin plasma the intensity ratio of the two lines of a species should be nearly the same as the ratio of the product of transition probability $\left(A_{k i}\right)$ and statistical weight $\left(g_{k}\right)$ and inverse ratio of their wavelength.

$\frac{I^{\prime}}{I^{\prime \prime}}=\frac{A_{k i}^{\prime} \cdot g_{k}^{\prime}}{A_{k i}^{\prime \prime} \cdot g_{k}^{\prime \prime}}$

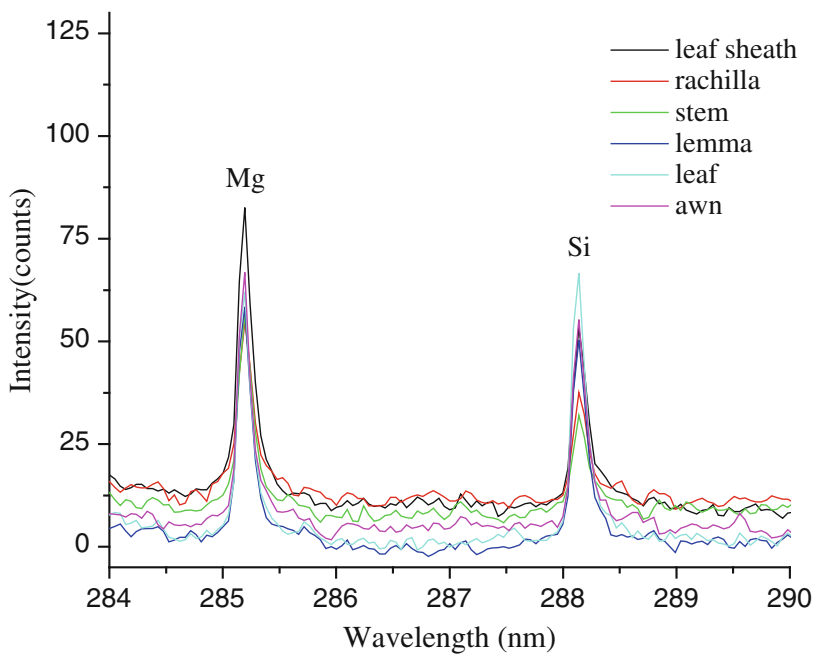

Fig. 7 Laser-induced breakdown spectroscopy (LIBS) spectra showing variation in concentration of $\mathrm{Mg}$ and $\mathrm{Si}$ in different parts of the plant

To verify Eq. (1) we took $\mathrm{Ca}$ (II) $315.8 \mathrm{~nm}$ and $\mathrm{Ca}$ (II) $317.9 \mathrm{~nm}$, whose intensity in the LIBS spectra were calculated using LIBS software and the values of $A_{k i}$ and $g_{k}$ were taken from the NIST basic atomic spectroscopic data table [40]. The value of $I^{\prime} / I^{\prime \prime}=1.8$ and $A_{k i}^{\prime} \cdot g_{k}^{\prime} /$ $A_{k i}^{\prime \prime} \cdot g_{k}^{\prime \prime}=1.7$, which shows that the plasma is optically thin. In order to ensure the LTE, electron density of plasma calculated from experimental results using stark broadening should be higher than the lower limit given by the relation [18]:

$N_{\mathrm{e}} \geq 1.6 \times 10^{12} T^{1 / 2} \Delta E^{3}$

Where $N_{\mathrm{e}}\left(\mathrm{cm}^{-3}\right)$ is electron density, $T(\mathrm{~K})$ is plasma temperature and $\Delta E(\mathrm{eV})$ is largest energy difference between two adjacent levels for allowed transition. The

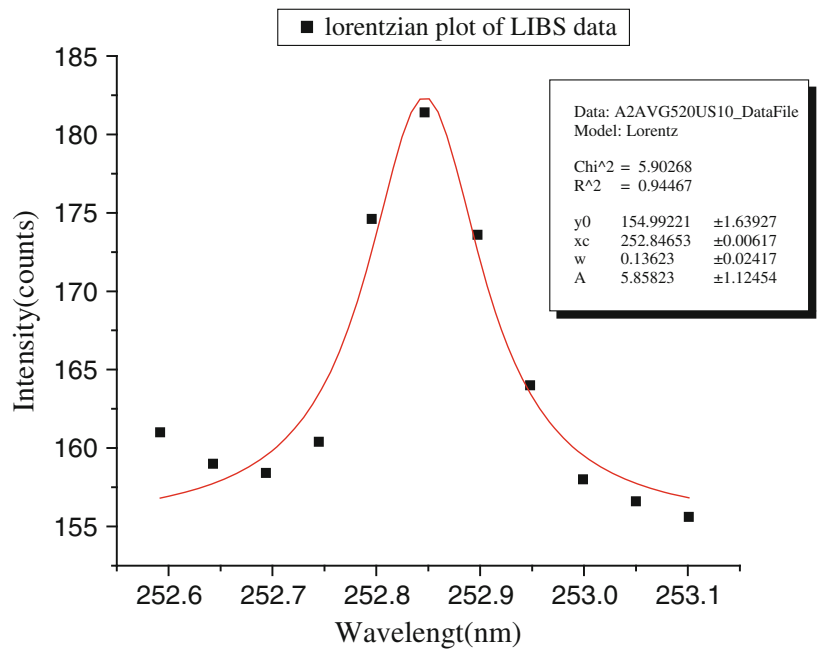

Fig. 8 Lorentzian plot of Si $252.8 \mathrm{~nm}$ for FWHM (full-width-halfmaximum) measurement 
electron density of an element in laser-induced plasma is related to the FWHM of stark broadening:

$\Delta \lambda_{1 / 2} \approx 2 w\left[\frac{N_{\mathrm{e}}}{10^{16}}\right]$

Where $\Delta \lambda 1 / 2(\mathrm{~nm})$ is stark broadening calculated from Fig. 8, $w(\AA)$ is an electron impact parameter obtained from spectroscopic data [18], and $N_{\mathrm{e}}\left(\mathrm{cm}^{-1}\right)$ is electron density. Temperature of plasma is calculated from the Boltzmann distribution law given by:

$I_{\lambda}^{k i}=C F A_{k i} g_{k} \frac{e^{-\left(E_{k} / k_{\mathrm{B}} T\right)}}{U(T)}$

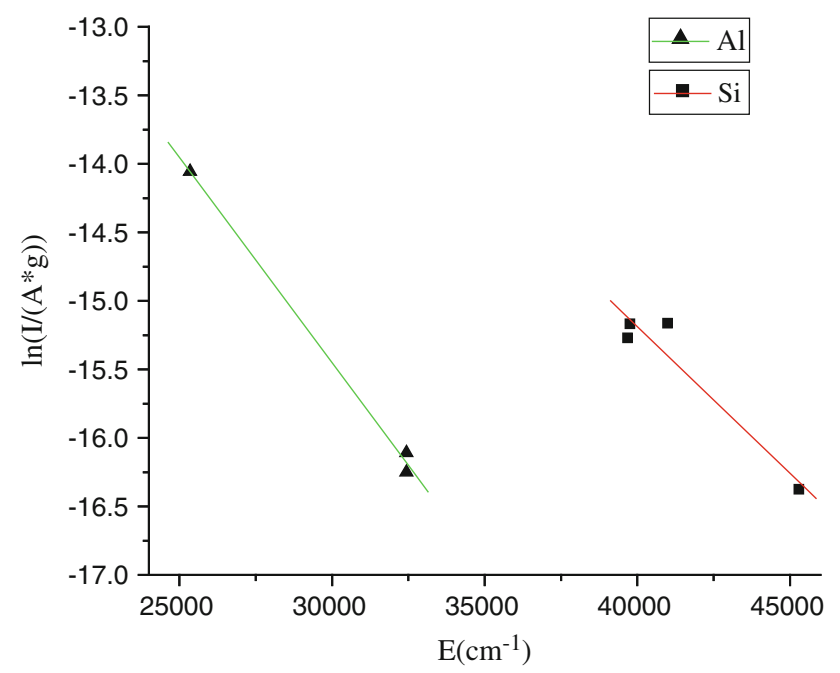

Fig. 9 Boltzmann plot for $\mathrm{Si}$ and $\mathrm{Al}$ for plasma temperature calculation

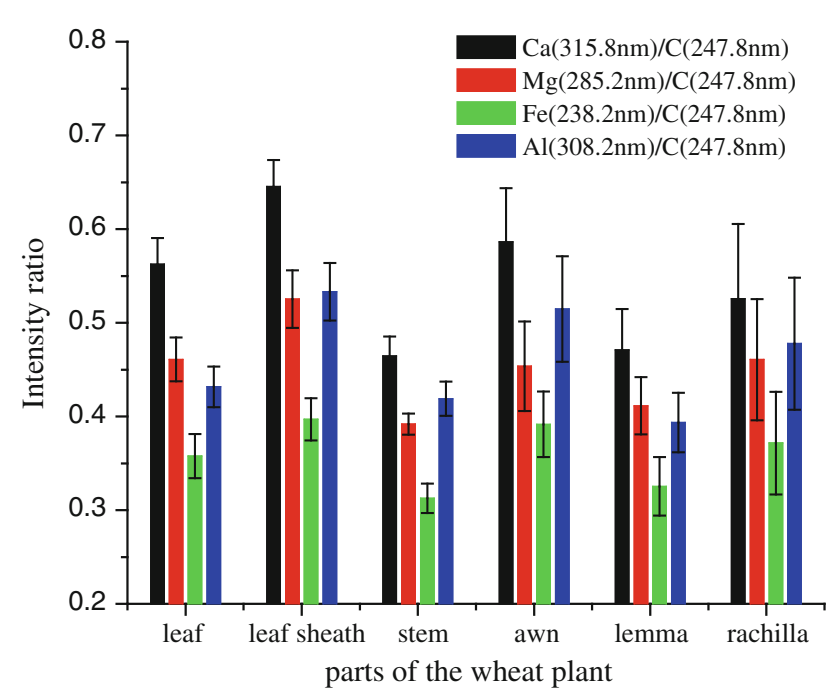

Fig. 10 Distribution of $\mathrm{Ca}, \mathrm{Mg}, \mathrm{Fe}$ and $\mathrm{Al}$
On rearranging the equation we get:

$\ln \left[\frac{I_{k i}^{\lambda}}{A_{k i} g_{k}}\right]=-\frac{E_{k}}{k_{\beta} T}+\ln \left[\frac{C F}{U(T)}\right]$

where $I_{k i}$ is intensity of a spectral line of wavelength $\lambda$, $k$ is Boltzmann's constant, $C$ is the concentration of the element, $U(T)$ is a partition function, $E_{k}$ is the upper energy level and $F$ is an experimental parameter. A plot of $\ln \left[I_{k i}{ }^{\lambda} / A_{k i} g_{k}\right]$ Vs $E_{k}$ is shown in Fig. 9 and the slope $(-1 /$ $\left.k_{\beta} T\right)$ gives the temperature of the laser induced plasma and is equal to $T 7,000 \mathrm{~K}$. The lower limit of electron density calculated from Eq. (2) is $2.28 \times 10^{16}\left(\mathrm{~cm}^{-3}\right)$. We also calculated the electron density by measuring the FWHM of the stark broadened line (Fig. 8) and using Eq. (3) and found it equal to $8.35 \times 10^{17}$, which verifies the existence

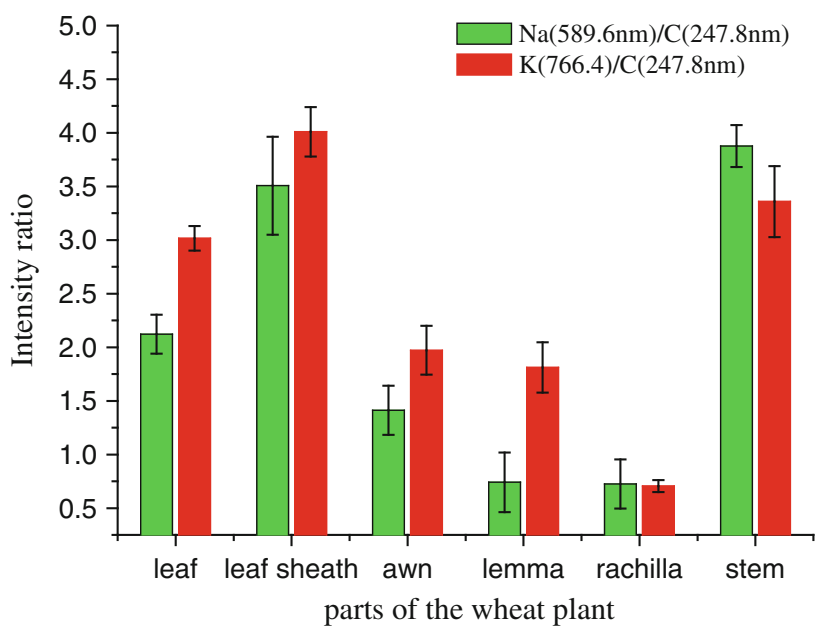

Fig. 11 Distribution of $\mathrm{Na}$ and $\mathrm{K}$

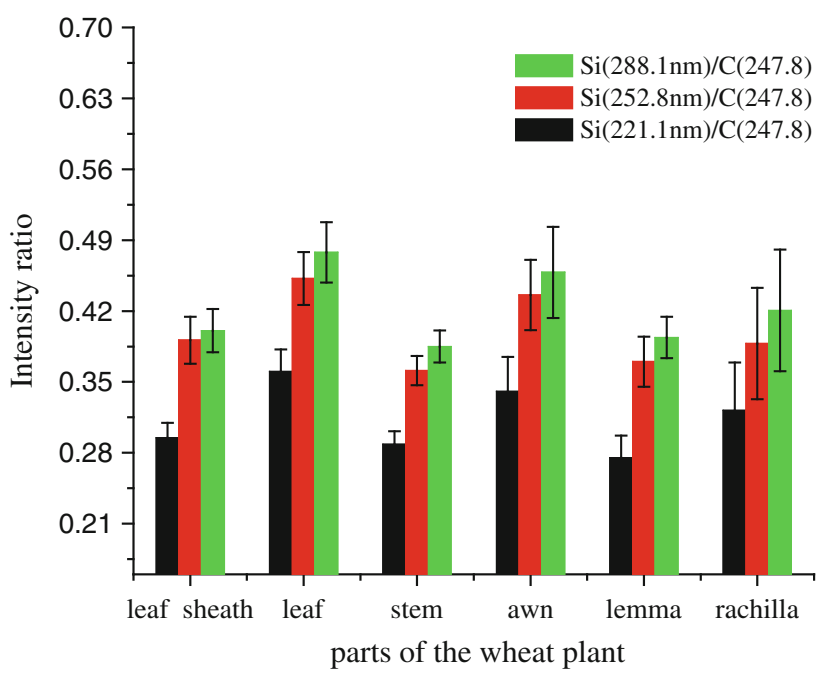

Fig. 12 Distribution of Si in different parts of the wheat plant for different wavelength of $\mathrm{Si}$ 

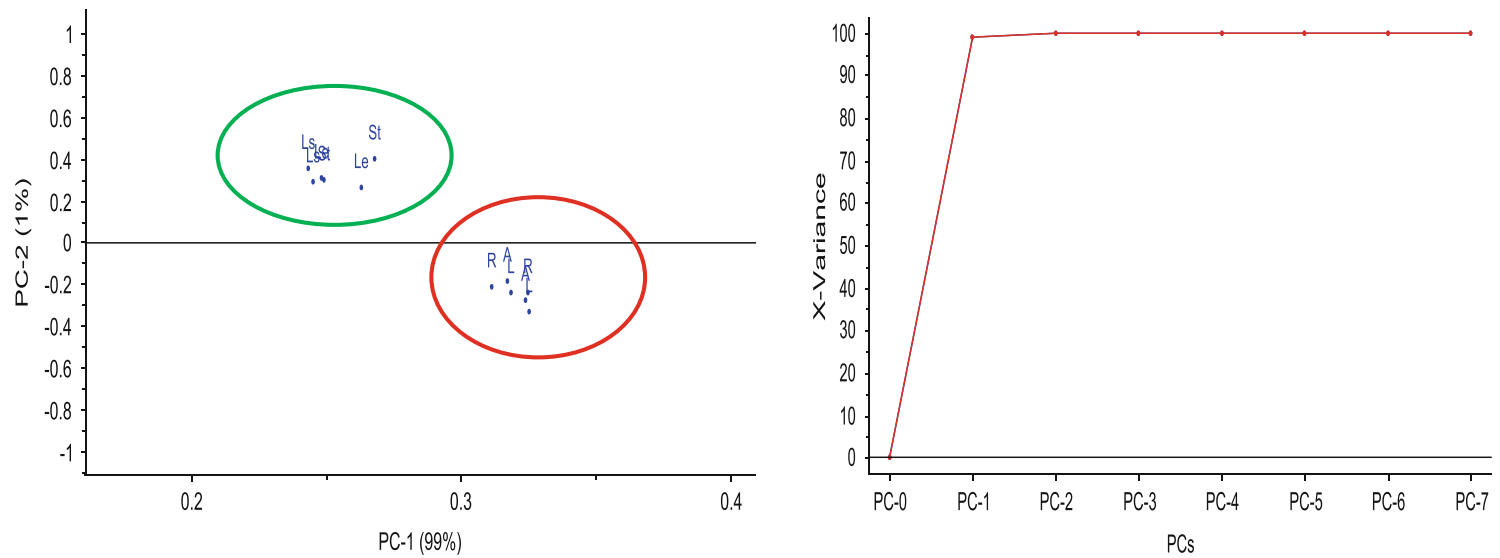

Fig. 13 Principal component analysis (PCA) plot showing clustering of the same group in the plant

of LTE in laser-induced plasma. Now the data of the LIBS spectra of the plant sample may be used for calculation of the intensity/concentration of the elements in the different parts of plant. To minimize the variation in experimental conditions we used the intensity ratio of the spectral lines of two elements instead of the absolute intensity of a spectral line. Intensity ratios of atomic lines of two different set of elements were evaluated from the LIBS spectra recorded from the different parts of the wheat plant and are shown in Figs. 10, 11 and 12. It is clear from Eq. 4 that the intensity of atomic lines of the elements in the laser-induced plasma is directly proportional to its concentration of the element in the sample. Thus, variation in the intensity of the atomic lines of elements (Figs. 10, 11 and 12) clearly demonstrates the variation in concentration of $\mathrm{Ca}, \mathrm{Mg}, \mathrm{Fe}, \mathrm{Na}, \mathrm{K}, \mathrm{Al}$ and $\mathrm{Si}$ in different parts of the wheat plant. These mineral elements play a significant role in development and growth of the plants as well as human life $[2,42,22]$. Intensity ratios of the atomic lines of $\mathrm{Si}(288.1,252.8,221.1 \mathrm{~nm})$ with the atomic line of C $(247.8 \mathrm{~nm})$ were determined from LIBS spectra of the different parts of the wheat plant and shown in Fig. 12. It is clear from Fig. 12 that highest intensity/concentration of silicon is present in leaf followed by the awn, leaf sheath, lemma, rachilla and stem, which is in close agreement with the results of phytolith analysis (Fig. 4). In the leaf blade, epidermal cells were heavily silicified so that the LIBS spectrum gives high concentration/intensity of silicon in the leaf blades, and it also support our previous study [6] that leaf contains the highest amount of silicon followed by the leaf sheath and stem. Grundbacher [19] concluded that awns accumulate high concentration of silica in their epidermal and hypodermal cells. Silicifications of the cells of awns provide the stiffness which protects the plants from various insects and pests attacks. The results of the LIBS analysis also demonstrate that the second most abundant silicon accumulator in the wheat plant is awn, while other parts like leaf sheath, lemma, stem and rachilla, accumulate less silicon and deposit in short cells. It has been reported that a heavy deposition of silicon within the plants depends on the transpiration stream that translocates silicon from the uptake site to the transpiration site $[13,29]$. To discriminate the pattern of silicon deposition in different parts of the plant using the LIBS technique we have used a statistical method known as principal component analysis (PCA). Principal component analysis of the data (intensity and wavelength of spectral lines) of the LIBS spectra of different parts of the wheat plant gives the PCA plot (Fig. 13). Two principal components, PC1 (99 \%) and PC2 $(1 \%)$, explain $100 \%$ variance within the data set and formulate two clusters in the PCA plot. Leaf, leaf sheath and stem create a first group of cluster while in the second a group of cluster of awn, lemma and rachilla are present. The leaf, leaf sheath and stem are the vegetative parts of the wheat plants and thus have analogous characters, while awn, lemma and rachilla are the fertile parts of the wheat plant which form similar cluster. Thus this may be the reason for the formation of two different groups in the PCA plot. On the basis of the experimental results of our work one may conclude that the LIBS technique can also sustain and resolve the physiological, aspects of plant science. Thus, the LIBS technique may be used as a versatile complementary tool with phytolith analysis.

\section{Conclusions}

The present work successfully demonstrates the capability of the LIBS technique for quick and simultaneous determination of elements including silicon present in the wheat (T. aestivum) plant. Results of the present paper further demonstrate that the LIBS technique may be used for the study of spatial distribution of minerals in plants. Analyses of silicon in different parts of the wheat plant using LIBS 
and phytolith analysis show similar results. However, with the help of phytolith analysis we can analyze only silicon, whereas LIBS can give the information about all elements present in the sample in a very small span of time. $\mathrm{Na}$ and $\mathrm{K}$ ratio in the food supplements have always been a matter of interest in the food science. Therefore, the ratio of $\mathrm{Na}$ and $\mathrm{K}$ in different parts of the wheat plant obtained by the LIBS analysis should be given more attention for better utilization of other parts of the wheat plant along with the seeds. Silicon is present in each part of the wheat plant, which reveals that wheat residues may also be used in ecofriendly biocement production as in recent years biocement production from the plant residues is a major thrust area of research. PCA of the LIBS data revealed the future possibilities of LIBS application in plant science.

Acknowledgments Financial assistance from the BRNS, BARC, and Mumbai (No. 2009/37/30/BRNS/2063) is gratefully acknowledged. Mr. Durgesh Kumar Tripathi is grateful to UGC for providing the D. Phil fellowship.

\section{References}

1. Alexandre A, Bremond L (2009) Comment on the paper in quaternary international: "methodological concerns for analysis of phytolith assemblages: does count size matter?' (C.A.E. Strömberg). Quat Int 193:141-142

2. Barker Allen V, Pilbeam DJ (2007) Handbook of plant nutrition. CRC, Boca Raton

3. Brasser HJ, Krijger GC, Wolterbeek HT (2008) On the beneficial role of silicon to organisms: a case study on the importance of silicon chemistry to metal accumulation in yeast. Biol Trace Elem Res 125:81-95

4. Britez RM, Watanabe T, Jansen S, Reissmann CB, Osaki M (2002) The relationship between aluminium and silicon accumulation in leaves of Faramea merginata (Rubiaceae). New Phytol 156:437-444

5. Brwen P, Menzies J, Ehert D, Samuels LADM (1992) Glass soluble silicon sprays inhibit powdery mildew development on grape leaves. J Am Soc Hortic Sci 117:906-912

6. Chauhan DK, Tripathi DK, Rai NK, Rai AK (2011) Detection of biogenic silica in leaf blade, leaf sheath, and stem of Bermuda grass (Cynodon dactylon) using LIBS and phytolith analysis. Food Biophys 6:416-423

7. Chauhan DK, Tripathi DK, Kumar D, Kumar Y (2011) Diversity, distribution and frequency based attributes of phytolith in Arundo donax L. Int J Innov Biol Chem Sci 1:22-27

8. Chen W, Yao X, Cai K, Chen J (2011) Silicon alleviates drought stress of rice plants by improving plant water status, photosynthesis and mineral nutrient absorption. Biol Trace Elem Res 142: $67-76$

9. Cocker KM, Evans DE, Hodson MJ (1998) The amelioration of aluminum toxicity by silicon in wheat (Triticum aestivum L.) malate exudation as evidence for an in planta mechanism. Planta 204:318-323

10. Dayanandan P, Kaufman PB, Franklin CI (1983) Detection of silica in plants. Am J Bot 70:1079-1084

11. Elawad SH, Green VE (1979) Silicon and the rice plant environment: a review of recent research. Rev Riso 28:235-253
12. Elliott CL, Snyder GH (1991) Autoclave-induced digestion for the colorimetric determination of silicon in rice straw. J Agric Food Chem 39:1118-1119

13. Epstein E (1999) Silicon. Annu Rev Plant Physiol Plant Mol Biol 50:641-664

14. Epstein E (2009) Silicon: its manifold roles in plants. Ann Appl Biol 155:155-160

15. Fraysse F, Pokrovsky OS, Schott J, Meunier JD (2006) Surface properties, solubility and dissolution kinetics of bamboo phytoliths. Geochim Cosmochim Acta 70:1939-1951

16. Fraysse F, Pokrovsky OS, Schott J, Meunier JD (2009) Surface chemistry and reactivity of plant phytoliths in aqueous solutions. Chem Geol 258:197-206

17. Gillman JH, Zlesak DC, Smith JA (2003) Applications of potassium silicate decrease black spot infection in Rosa hybrida $>$ Meipelta $=($ Fuschia Meidland). Hortic Sci 38:1144-1147

18. Griem HR (1964) Plasma spectroscopy. McGraw Hill, New York

19. Grundbacher FJ (1963) The physiological function of the cereal awn. Bot Rev 29:366-381

20. Haysom MB, Ostatek-Boczynski ZA (2006) Rapid wet oxidation procedure for the estimation of silicon in plant tissue. Commun Soil Sci Plant Anal 37:2299-2306

21. Hodson MJ, White PJ, Mead A, Broadley MR (2005) Phylogenetic variation in the silicon composition of plants. Ann Bot 96 : 1027-1046

22. Hopkins WG, Huner Norman PA (2008) Introduction to plant physiology, 4th edn. Wiley, University of Western Ontario

23. Hosseini MM, Shao Y, Whalen JK (2011) Biocement production from silicon-rich plant residues: perspectives and future potential in Canada. Biosyst Eng 110:351-362

24. Jiang-yu F, Xue-long Ma (2006) In vitro simulation studies of silica deposition induced by lignin from rice. J Zhejiang Univ Sci B 7:267-271

25. Jones LHP, Handreck KA (1967) Silica in soils, plants and animals. Adv Agron 19:107-149

26. Korndorfer GH, Lepsch I (2001) Effect of silicon on plant growth and crop yield. In: Datonoff L, Korndorfer G, Synder G (eds) Silicon in agriculture. Elsevier Science, New York, pp 133-147

27. Lanning CF (1966) Relation of silica in wheat to disease and pest resistance. J Agric Food Chem 14:350-352

28. Ma J, Takahashi E (2002) Soil, fertilizer and plant silicon research in Japan. Elsevier Science, The Netherlands

29. Ma FJ, Yamaji N (2006) Silica uptake and accumulation in higher plants. Trend Plant Sci 11:8

30. Ma FJ, Tamai K, Yamaji N, Mitani N, Konishi S, Katsuhara M, Ishiguro M, Murata Y, Yano MA (2006) Silicon transporter in rice. Nature 440:668-691

31. Madella M, Alexandre A, Ball T (2005) International code for phytolith nomenclature 1.0. Ann Bot 96:253-260

32. Marschner H (1995) Mineral nutrition of higher plants. Academic Press, London

33. Masson P, Dauthieu M, Trolard F, Denaix L (2007) Application of direct solid analysis of plant samples by electrothermal vaporization inductively coupled plasma atomic emission spectrometry: determination of $\mathrm{Cd}$ and $\mathrm{Si}$ for environmental purposes. Spectrochim Acta Part B At Spectrosc 62:224-230

34. Novozamsky I, Vaneck R, Houba VJG (1984) A rapid-determination of silicon in plant material. Commun Soil Sci Plant Anal 15:205-211

35. Pathak AK, Singh VK, Rai NK, Rai AK, Rai PK, Rai PK, Rai S, Baruah GD (2011) Study of different concentric rings inside gallstones with LIBS. Laser Med Sci 26:531-537

36. Ponzi R, Pizzolongo P (2003) Morphology and distribution of epidermal phytoliths in triticum aestivum. Plant Biosyst 137:3-10

37. Raven JA (2003) Cycling silicon: the role of accumulation in plants. New Phytol 158:419-421 
38. Rodrigues FÁ, McNally DJ, Datnoff LE, Jones JB, Labbe C, Benhamou N, Menzies JG, Bélanger RR (2004) Silicon enhances the accumulation of diterpenoid phytoalexins in rice: a potential mechanism for blast resistance. Phytopathology 94:177-183

39. Saito K, Yamamoto A, Sa T, Saigusa M (2005) Rapid, micromethods to estimate plant silicon content by dilute hydrofluoric acid extraction and spectrometric molybdenum method. Soil Sci Plant Nutr 51:29-36

40. Sansonetti JE, Martin WC (2005) Hand book of basic atomic spectroscopic data. J Phys Chem Ref Data 34:1559-2259

41. Savant NK, Korndorfer GH, Datnoff LE, Snyder GH (1999) Silicon nutrition and sugarcane production: a review. J Plant Nutr 22:1853-1903

42. Seckback J (1982) Ferreting out the secrets of plants ferritin: a review. J Plant Nutr 5:201-205

43. Singh JP, Thakur SN (2007) Laser induced breakdown spectroscopy. Elsevier Science, UK

44. Singh VP, Tripathi DK, Kumar D, Chauhan DK (2011) Influence of exogenous silicon addition on aluminium tolerance in rice seedlings. Biol Trace Elem Res. doi:10.1007/s12011-011-9118-6

45. Stebbins GL (1938) A bleaching and clearing method for plant tissues. Science 87:21-22

46. Strömberg CAE (2009) Methodological concerns for analysis of phytolith assemblages: does count size matter? Quat Int 193: 124-140

47. Takahashi E, Miyake Y (1976) Distribution of silica accumulator in plant kingdom. J Sci Soil Manure, Japan 47:296-300

48. Takahashi E, Ma JF, Miyake Y (1990) The possibility of silicon as an essential element for higher plants. Comments Agric Food Chem 2:99-122
49. Tripathi DK, Singh VP, Kumar D, Chauhan DK (2011) Rice seedlings under cadmium stress: effect of silicon on growth, cadmium uptake, oxidative stress, antioxidant capacity, and root and leaf structures. Chem Ecol 28:281-291

50. Tripathi DK, Singh VP, Kumar D, Chauhan DK (2012) Impact of exogenous silicon addition on chromium uptake, growth, mineral elements, oxidative stress, antioxidant capacity, and leaf and root structures in rice seedlings exposed to hexavalent chromium. Acta Physiol Plantarum 34:279-289. doi:10.1007/s11738-0110826-5

51. Twiss PC (1987) Grass-opal phytoliths as climatic indicators of the Great Plains Pleistocene. In: Johnson WC (ed) Quaternary environments of Kansas. Kansas Geological Survey, Lawrence, pp 179-188

52. Twiss PC, Suess E, Smith RM (1969) Morphological classification of grass Phytoliths. J Soil Sci Soc Am 33:109-115

53. Yoshida S (1975) The physiology of silicon in rice. Technical Bulletin 25, Food and Fertilizer Technology Center, Taipei, Taiwan

54. Yoshida S, Ohnishi Y, Kitagishi K (1962) Histochemistry of silicon in rice plant. I. A new method for determining the localization of silicon within plant tissues. Soil Sci Plant Nutr 8: 30-35

55. Yoshida S, Forno DA, Cock JH, Gomez KA (1976) Laboratory manual for physiological studies of rice. International Rice Research Institute, Los Bano, pp 17-22

56. Zsoldos F, Vashegyi A, Bona L, Pécsváradi A, Szegletes ZS (2000) Growth and potassium transport of winter wheat and durum wheat as affected by various aluminum exposure times. J Plant Nutr 23:913-926 